\title{
Pithecellobium dulce, Tagetes erecta and Cosmos bipinnatus on reducing enteric methane emission by dairy cows
}

\section{Gloria Stefanny Hernández Pineda ${ }^{1}$ - Paulina Elizabeth Pedraza Beltrán ${ }^{1} \odot$ Mohammed Benaouda $^{1}$ José Manuel Palma García ${ }^{2}$-) Francisca Avilés Nova $^{3} \odot$ Luisa Molina ${ }^{4}$ Octavio Alonso Castelán Ortega ${ }^{*} \odot$}

'Facultad de Medicina Veterinaria y Zootecnia, Universidad Autónoma del Estado de México (UAEMex), 50000, Toluca, México. E-mail: oacastelano@uaemex.mx. "Corresponding author.

${ }^{2}$ Facultad de Medicina Veterinaria y Zootecnia, Universidad de Colima (U. de C.), Tecoman, Colima, México.

${ }^{3}$ Centro Universitario Temascaltepec, Universidad Autónoma del Estado de México, Temascaltepec de González, México, México.

${ }^{4}$ Molina Center for Energy and the Environment, La Jolla, California, United States of America.

ABSTRACT: The aim of the present research was to evaluate the effect of Pithecellobium dulce, Tagetes erecta and Cosmos bipinnatus on methane emission, milk yield and dry matter intake in dairy cattle. A $4 \times 4$ Latin square experimental design was employed, using four multiparous Holstein cows of $553 \pm 72.4 \mathrm{~kg}$ body weight, at mid lactation and average milk yield of $17.3 \pm 3 \mathrm{~kg} /$ day. The experiment lasted 92 days, divided into four experimental periods of 23 days each. All cows had free access to maize and alfalfa silage in a 50:50 proportion, $4 \mathrm{~kg}$ of concentrate/day and ad libitum access to water. Treatments consisted in supplementation of $0.5 \mathrm{~kg} /$ day of the experimental plants, with one control treatment without supplementation. Each cow received one of each treatment in turn during one of the four periods. The C. bipinnatus reduced methane production by $16 \%(P<0,05)$ in comparison with the control diet. Milk production, milk composition and dry matter intake were not affected $(p>0$ 0.05) by the use of C. bipinnatus or any other plant species. Supplementation at low doses of C. bipinnatus showed a reduction in ruminal methane production in dairy cows.

Key words: methane, cattle, climate change, mitigation, tannins.

\section{Pithecellobium dulce, Tagetes erecta e Cosmos bipinnatus na redução} de emissão de metano por vacas leiteiras

RESUMO: O objetivo deste estudo é avaliar o efeito do Pithecellobium dulce, Tagetes erecta e o Cosmos bipinnatus na emissão do metano, a produção de leite e de ingestão diária de matéria seca pelo gado. Um desenho experimental do quadrado latino $4 x 4$ foi usado, com quatro

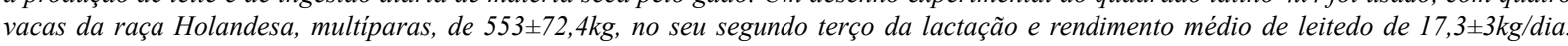
O experimento durou 92 dias e foi dividido em quatro periodos de 23 dias cada um. Das vacas tinham acesso livre a milho e silagem de alfafa, numa proporção de 50:50, com $4 \mathrm{~kg}$ de concentrado por dia, com acesso a água ad libitum. Os tratamentos consistiram na ingestão de $0,5 \mathrm{~kg}$ por dia, com as plantas experimentais; as vacas no tratamento de controle não receberam nenhuma planta, porém, elas receberamum tratamento, em cada um dos quatro periodos. O C. bipinnatus reduziu significativamente a produção de metano em $16 \%(P<0,05)$, em comparação com a dieta controle. A produção de leite, sua composição e o consumo de matéria seca não foram afetados $(P>0,05)$ pelo uso de C.bipinnatus ou outras espécies de plantas. A ingestão com doses baixas de C. bipinnatus, que é uma planta arbustiva com um centéudo moderado de taninos, mostrou ter potencial para reduzir a produção de metano ruminal em vacas leiteiras.

Palavras-chave: metano, gado, mudança climática, mitigação, taninos.

\section{INTRODUCTION}

The main sources of anthropogenic methane $\left(\mathrm{CH}_{4}\right)$ are the production of ruminants for meat and milk production, the extraction and use of fossil fuels, and rice production. Agriculture contributes to approximately $13 \%$ of the total global emission of greenhouse gases (GHG) (IPCC, 2014), of which cattle are responsible for 53\% (CHARMLEY et al., 2016). Thus, several studies, mostly in vitro experiments, have been conducted on the effect of tanniferous plants on reducing rumen $\mathrm{CH}_{4}$ production, in order to find natural alternatives to mitigate the environmental impact generated by the emissions of this GHG by the cattle industry (CUARTAS et al., 2014). However, results in literature are contradictory, because in some cases a small methane reduction has been observed whereas in others a large reduction potential was identified. For example, NAUMANN et al. (2013) observed a small $\mathrm{CH}_{4}$ reduction of $3.2 \%$ and $0.5 \%$ in an experiment conducted to evaluate the in vitro effect of two types of Acacia angustissima - the South Texas ecotype and Cross timbers ecotype - with a condensed tannin content of $8.4 \%$ and $8.9 \%$, respectively. Similarly, in a study conducted by BHATTA et al. (2009) in order 
to evaluate the effect of different tannins (in their pure form) on in vitro $\mathrm{CH}_{4}$ production, it was observed that hydrolysable tannins reduced $\mathrm{CH}_{4}$ production by only $0.6 \%$, while a mixture of hydrolysable and condensed tannins reduced it by $5.5 \%$. Unfortunately, there are few studies where the effects of entire tanniferous plants on rumen methano genesis in cattle and animal performance have been evaluated in vivo (PATRA \& SAXENA 2010). For example, BEAUCHEMIN et al. (2007) conducted an experiment to determine if $1 \%$ and $2 \%$ of dietary DM as condensed quebracho tannin extract could be used to reduce enteric $\mathrm{CH}_{4}$ emissions in cattle. They used six spayed Angus heifers and 6 Angus steers and concluded that feeding with up to $2 \%$ of dietary DM as quebracho tannin extract failed to reduce enteric methane emissions from growing cattle. No information was reported in the literature on the in vivo anti-methanogenic properties of Tagetes erecta, Cosmos bipinnatus and Pithecellobium dulce. However, our group conducted several in vitro studies to evaluate the potential of Tagetes erecta for reducing $\mathrm{CH}_{4}$ production; for example, ANDRADE et al. (2012) observed a reduction of $39 \%$ in comparison with a control diet. Similarly, MAHMOUD et al. (2016) reported a $35 \%$ reduction $(p<0.05)$ in methane production in comparison with a control diet when only $10 \%$ dietary dry matter (DM) of $T$. erecta was included in the diet. Likewise, a reduction of $11 \%$ $(\mathrm{P}<0,001)$ in methane production was also reported by MAHMOUD et al. (2017) with the inclusion of only $10 \%$ of dietary DM of C. bipinnatus in the experimental diet. These studies also suggested that the anti-methanogenic capacity of $T$. erecta and $C$. bipinnatus is not linear but quadratic, and that the best effect was observed at low inclusion levels. Therefore, it was hypothesized that $T$. erecta, $C$. bipinnatus and $P$. dulce could reduce in vivo methane production and that this effect could be detected at low inclusion levels without affecting animal productive performance. The objective of the present study was to evaluate the effect of supplementation of Tagetes erecta, Cosmos bipinnatus and Pithecellobium dulce on reducing enteric methane emission, and on milk production and dry matter intake in dairy cattle.

\section{MATERIALS AND METHODS}

Area of study

The experiment was conducted at the Laboratory for Research on Livestock, Environment and Renewable Energies of the Faculty of Veterinary Medicine and Animal Science of the Universidad Autónoma del Estado de México, located in Toluca,
State of Mexico, Mexico at $19^{\circ} 27^{\prime} \mathrm{N}$ and $98^{\circ} 38^{\prime} \mathrm{W}$ and $2600 \mathrm{~m}$.a.s.1.

\section{Experimental design:}

A $4 \times 4$ Latin square experimental design was employed, using four multiparous Holstein cows of $553 \pm 72.4 \mathrm{~kg}$ of body weight, at mid lactation and average milk yield of $18 \pm 3 \mathrm{~kg} /$ day. The experiment lasted 92 days, which were divided into four experimental periods of 23 days each. All cows had free access to maize-alfalfa silage in a 50:50 proportion, $4 \mathrm{~kg}$ of concentrate/day and ad libitum access to water. The concentrate was composed of $48.7 \%$ corn, $20 \%$ soya bean, $14.8 \%$ canola bean, $14.7 \%$ wheat bran and $1.8 \%$ of mineral premix. The four treatments consisted of the supplementation of $0.5 \mathrm{~kg} \mathrm{DM} /$ day $/$ cow for each of the three experimental plants plus the control, which was the diet alone without the addition of experimental plants. Each cow received each treatment in turn, once in each of the four periods. Before the beginning of the trial, the experimental plants were dried over a period of 8 weeks away from sunlight to prevent denaturalization of phenolic compounds as indicated in MAKKAR et al. (1993). Once dried they were ground and incorporated into the concentrate to ensure that the cows would eat the entire daily ration provided, as the aim of the experiment was to evaluate the effect of the entire plants and not only the effect of the phenolic compounds within them. Samples of the experimental plants were collected for later chemical analysis in the laboratory. For each 23day experimental period, 15 days were used for diet adaptation and the remaining to measure methane production, dry matter intake and digestibility of the diet. The cows were confined in individual pens of $4 \times 4 \mathrm{~m}$, equipped with drinker and trough, throughout the experiment. Milk yield was weighed daily during the entire 23-day period and milk composition was evaluated daily during the measuring period of eight days. A Lactichek ${ }^{\mathrm{TM}}$-01 (Rapi Read, Page \& Pedersen International Ltd. Hopkinton, Massachusetts) analyzer was used to determine milk composition: fat, lactose, protein, non-fat milk solids. Body weight was measured once at the beginning and once at the end of each experimental period. We used adult cows and the body weight was recorded only. Dry matter intake (DMI) was determined by weighing the silage and concentrate offered in the morning and collecting and weighing the rejected feed the next morning. The difference between the offered feed minus the rejected feed was the daily DMI. Digestibility of the dry matter (DMD) was calculated as shown in equation 
(1). Samples of silage were taken every week for later chemical analyses in the laboratory.

$D M D(\%)=((D M I-F A e) / D M I) \times 100$

Where: $\mathrm{DMI}=$ dry matter intake in $\mathrm{kg}$ ofDM,FAe=feces weight in $\mathrm{kg}$ of DM.

\section{Methane production measurement:}

The $\mathrm{CH}_{4}$ production was measured with a respiration chamber of the head-box type as described previously in PEDRAZA-BELTRÁN et al. (2016). The $\mathrm{CH}_{4}$ analyzer that was used measures emissions highly accurately over a wide range by combining noise amplification and signal processing with a computerized controller and digital filtering to provide a maximum resolution of $0.0001 \%$ to $0.01 \%$. Before each assay two calibrations of this instrument were performed: a zero calibration using high-purity nitrogen $\left(\mathrm{N}_{2}\right)$ (Praxair Inc., Mexico), and a calibration against a reference gas, which is also known as a span gas. The $\mathrm{N}_{2}$ in the zero calibration was first passed through a drying unit to remove moisture and then through the analyzer at a flow rate of $0.3 \mathrm{~L} / \mathrm{min}$ to obtain a reading close to zero. The span calibration was performed using a known $\mathrm{CH}_{4}$ concentration gas mixture (1000ppm of $\mathrm{CH}_{4}$ in high-purity $\mathrm{N}_{2}$ ). The span gas passed through the analyzer $(0.3 \mathrm{~L} / \mathrm{min})$ to obtain a reading corresponding to the concentration of $\mathrm{CH}_{4}$ in the span gas. Every assay started at 10:00h, the mass flow generator was set at $480 \mathrm{~L} / \mathrm{min}$, the analyzer was set to measure $\mathrm{CH}_{4}$ concentration every second and then the chamber was closed. The $\mathrm{CH}_{4}$ emissions were measured for 24-h period. The cows were removed from the chamber for milking at $6: 00 \mathrm{~h}$ and $15: 00 \mathrm{~h}$, and each milking lasted $1.5 \mathrm{~h}$, subsequently they were returned to the chamber. The diet was weighed before the beginning of the assay, and all animals were given the same amount at the same time (9:00h and 16:00h). The next morning, the orts were removed and weighed to calculate DMI. Diet samples were collected and kept in a freezer until laboratory analysis. Feces were collected and weighed at the end of each measurement. A sample of approximately $1 \mathrm{~kg}$ of feces was obtained and kept frozen until laboratory analysis. Four assays were completed in each experimental period.

\section{Chemical analysis of the feed}

Silage, concentrate feed and stool samples were dried in a forced air oven at $60^{\circ} \mathrm{C}$ for $72 \mathrm{~h}$ until constant weight was obtained, then later ground and passed through a 1-mm sieve. The DM and organic matter $(\mathrm{OM})$ contents were determined according to the procedures of the Official Methods of Analysis
(AOAC, 1997). The nitrogen content in the silage and concentrate was determined by the Kjeldhal method (AOAC, 1997), and subsequently multiplied by a factor of 6.25 to obtain the protein content. The neutral detergent fiber (NDF), acid detergent fiber (ADF) and lignin contents were determined by the method of VAN SOEST et al. (1991) using an ANKOM A200 fiber analyzer (Technology Corporation, Fairport, NY, USA). The DM content in the silage was corrected as in HAIGH (1995) to include the volatile solids in the DM. The concentration of total phenols in the experimental plants was determined by the Folin-Ciocalteu method and the tannin content by the polyvinylpolypyrrolidone method as described in MAKKAR (1993). Table 1 shows the chemical composition of silage and concentrates, and the phenol and tannin content of the experimental plants.

\section{Analysis of results}

The experimental variables were analyzed with an analysis of variance for a Latin square experimental design as shown in equation 2 . In order to eliminate Type II error (KAPS \& LAMBERSON 2009) the Fisher's Least Significant Difference (LSD) test between control and treatment means was also carried out. The analytical procedures were carried out using the lmer function of the lme4 package (BATES et al., 2015) in R software (R core team, 2016). Post hoc pairwise comparison was carried out using the Tukey HSD test using the lsmeans function in the lsmeans package (LENTH, 2016).

$Y_{i j k}=\mu+T X_{i}+$ Per $_{j}+$ Cow $_{k}+\varepsilon i j k$ where $\mathrm{Y}_{\mathrm{ijk}}$ is the individual observation, $\mu$ is the overall mean, $\mathrm{TX}_{\mathrm{i}}$ is the fixed effect of treatment (i $=1,2,3$, and 4), Per is the effect of period $(j=1,2$, 3 , and 4 ; treated as a random effect), Cow ${ }_{k}$ is the effect of cow $(\mathrm{k}=1,2,3$, and 4 ; treated as a random effect) and $\varepsilon_{\mathrm{ijk}}$ is the residual error term. A multiple correlation analysis between all variables was also performed in order to find associations that help in explaining $\mathrm{CH}_{4}$ production. The corr plot routine from the corr plot v.0.77 package (WEI \& VILIAM 2016) of the R software v.3.2.2. was used (R, CORE TEAM, 2011).

\section{RESULTS}

Table 2 shows the effect of the experimental plants on DMI, DMD, milk yield and $\mathrm{CH}_{4}$ production. Results show that no differences $(\mathrm{P}>0,05)$ were observed between the control and the treatments for all variables except for $\mathrm{CH}_{4}$ production. The treatment with $C$. bipinnatus reduced $\mathrm{CH}_{4}$ production 
Table 1 - Chemical composition of the silage and concentrate; and chemical composition, total phenols and total tannin concentration of the experimental plants (all in $\mathrm{g} / \mathrm{Kg}$ of DM, except DM, which is $\mathrm{g} / \mathrm{Kg}$ ).

\begin{tabular}{|c|c|c|c|c|c|}
\hline Item & Concentrate & Silage & Pithecellobium dulce & Cosmos bipinnatus & Tagetes erecta \\
\hline DM & 888.5 & 367.2 & 931.5 & 928.1 & 931.5 \\
\hline $\mathrm{OM}$ & 826.4 & 890.8 & 852.8 & 821.7 & 846.6 \\
\hline $\mathrm{CP}$ & 221.1 & 108.4 & 90.5 & 115.2 & 137.2 \\
\hline $\mathrm{NDF}$ & 340.7 & 517.8 & 527.1 & 470.5 & 458.7 \\
\hline $\mathrm{ADF}$ & 123.5 & 390.3 & 468.3 & 387.3 & 403.8 \\
\hline Lignin & 40.2 & 102.2 & 184.0 & 96.2 & 76.4 \\
\hline Hemicellulose & 217.2 & 127.5 & 58.7 & 83.2 & 54.9 \\
\hline Cellulose & 83.3 & 288.1 & 284.3 & 291.1 & 327.4 \\
\hline Total phenols & - & - & 49.2 & 80.6 & 99.4 \\
\hline Total tannins & - & - & 22.8 & 69.7 & 78.1 \\
\hline
\end{tabular}

OM organic matter, $\mathrm{CP}$ crude protein, NDF neutral detergent fiber, ADF acid detergent fiber.

by $98.2 \mathrm{~L} /$ day $(<16 \%)$ relative to the control $(\mathrm{P}<0,05)$, whereas $P$. dulce and T. erecta showed no effect on $\mathrm{CH}_{4}$ production $(\mathrm{P}>0,05)$. The LSD between the control and $P$. dulce was $86.9 \mathrm{~L} /$ day $(\mathrm{P}<0,05)$. All the productive parameters, such as body weight, milk yield, DMI and DMD were not affected by any of the plants tested at the level they were supplemented. Percentages of each plant in relation to the total dry matter intake for the treatments of control, P. dulce, $C$. bipinnatus and T. erecta were 3.5, 2.6, 3.6 and 3.1\%, respectively. Milk composition was also unaffected $(\mathrm{P}>0,05)$ by the experimental plants, as shown in Table 3. The multiple correlation analysis showed positive associations between $\mathrm{CH}_{4} \mathrm{~L} /$ day and DMI $(\mathrm{r}=0,5, \mathrm{P}<0,05)$, and between $\mathrm{DMD}$ and $\mathrm{CH}_{4} \mathrm{~L} /$ day $(\mathrm{r}=0.6, \mathrm{P}<0,01)$. In contrast, a negative association $(\mathrm{r}=-0.64, \mathrm{P}<0,001)$ was observed between milk yield and $\mathrm{CH}_{4}$ in $\mathrm{L} / \mathrm{Kg}$ of milk. No other association was observed among the studied variables. A large numerical difference of $22.4 \mathrm{~L}$ was observed between the control and $P$. dulce treatments for the variable $\mathrm{CH}_{4}, \mathrm{~L} / \mathrm{kg}$ of DMD; however, this was not significant since the LSD is $53 \mathrm{~L}(\mathrm{P}>0,05)$.

\section{DISCUSSION}

The $\mathrm{CH}_{4}$ production for individual cows in the control treatment was within the range reported for animals of similar body live weight and intake (NIU et al., 2016). On the other hand, the percentage

Table 2 - Effect of supplementation with P. dulce, C. bipinnatus and T. erecta on methane production, dry matter intake, dry matter digestibility, live weight and milk yield.

\begin{tabular}{|c|c|c|c|c|c|c|}
\hline Item & Control & Pithecellobium dulce & Cosmos bipinnatus & Tagetes erecta & S.E. & $P$ value \\
\hline Live weight, $\mathrm{Kg}$ & $568 \pm 63$ & $583 \pm 57$ & $576 \pm 68$ & $569 \pm 69$ & 5.6 & 0.31 \\
\hline DMI, $\mathrm{kg} \mathrm{DM} / \mathrm{d}$ & $14.7 \pm 3$ & $19.7 \pm 6$ & $14.5 \pm 3$ & $16.8 \pm 4$ & 1.9 & 0.28 \\
\hline DMD, $\%$ & $55.6 \pm 6$ & $62.8 \pm 9$ & $58.8 \pm 16$ & $62.5 \pm 12$ & 7.3 & 0.71 \\
\hline $\mathrm{CH}_{4}, \mathrm{~L} / \mathrm{d}$ & $613.5 \pm 97^{\mathrm{a}}$ & $635.5 \pm 105^{\mathrm{a}}$ & $515.3 \pm 41^{\mathrm{b}}$ & $541.5 \pm 49^{\mathrm{ab}}$ & 25.1 & 0.04 \\
\hline Milk, Kg/d & $17.3 \pm 3$ & $17.4 \pm 3$ & $16.9 \pm 3$ & $15.7 \pm 3$ & 0.95 & 0.6 \\
\hline $\mathrm{CH}_{4}, \mathrm{~L} / \mathrm{Kg}$ of DMI & $43 \pm 11$ & $34 \pm 8$ & $36.7 \pm 7$ & $33.3 \pm 7$ & 4.8 & 0.41 \\
\hline $\mathrm{CH}_{4}, \mathrm{~L} / \mathrm{Kg}$ of DMD & $76.9 \pm 29$ & $54.5 \pm 20$ & $64.8 \pm 25$ & $55.4 \pm 25$ & 15.3 & 0.7 \\
\hline $\mathrm{CH}_{4}, \mathrm{~L} / \mathrm{Kg}$ of milk & $36.9 \pm 9$ & $38 \pm 12$ & $30.8 \pm 3$ & $34.9 \pm 5$ & 2.63 & 0.35 \\
\hline
\end{tabular}

$\pm=$ standard deviation, S.E.= standard error, $\mathrm{DMI}=$ dry matter intake, $\mathrm{DMD}=$ dry matter digestibility, values in the same row with different superscripts indicate differences $\mathrm{p}<0.05$. 
Table 3 - Effect of supplementation with P. dulce, C. bipinnatus and T. erecta on milk composition (\%).

\begin{tabular}{lcccccc}
\hline & & & & & & \\
Item & Control & Pithecellobium dulce & Cosmos bipinnatus & Tagetes erecta & S.E. & P value \\
Fat & $4.2 \pm 0.70$ & $3.7 \pm 0.10$ & $3.9 \pm 0.86$ & $4.0 \pm 0.55$ & 0.18 \\
Protein & $3.4 \pm 0.08$ & $3.3 \pm 0.07$ & $3.4 \pm 0.16$ & $3.4 \pm 0.08$ & 0.03 \\
Non-fat solids & $9.0 \pm 0.20$ & $8.8 \pm 0.20$ & $9.1 \pm 0.41$ & $9.0 \pm 0.21$ & 0.19 \\
Density & $31.2 \pm 0.36$ & $30.7 \pm 0.82$ & $31.8 \pm 1.10$ & $31.4 \pm 0.49$ & 0.30 \\
\hline
\end{tabular}

$\pm=$ standard deviation. S.E. $=$ standard error.

of $\mathrm{CH}_{4}$ reduction was achieved due to the inclusion of $C$. bipinnatus and was comparable to the values reported in similar studies, even though the percentage of plants in the diet and the tannin content, $2.6 \%$ and $69.7 \mathrm{~g} / \mathrm{kg}$ of plant's DM respectively, were lower than in most published studies. This confirmed our hypothesis that the supplementation of small quantities of this experimental plant can reduce in vivo methane emission by adult cows. The inclusion rate of experimental plants in our research ranged from 2.6 to $3.1 \%$ of the average total DMI, whereas in similar studies the supplementation rate is significantly higher. For example, PIÑEIRO et al. (2017) evaluated the effect of increasing levels of Leucaena leucocephala $(0,20,40,60$ and $80 \%)$ on methane production in heifers fed with a low-quality diet. The DM intake in their work ranged from 7 to $7.15 \mathrm{~kg}$ of $\mathrm{DM} /$ day, meaning that the intake of L. leucocephala reached up to $5.72 \mathrm{~kg}$ of DM/day at an $80 \%$ inclusion level. In other studies, the tanniferous plant constituted $100 \%$ of the diet, as in in WOODWARD et al. (2002), where dairy cows were fed only with Hedysarum coronarium with no effect on daily $\mathrm{CH}_{4}$ production. The reduction in methanogenesis observed for $C$. bipinnatus may be attributed to the higher content of total tannins than $P$. dulce, although $T$. erecta has more tannins than $C$. bipinnatus. This suggested that it may be the type of tannins, particularly condensed tannins that may be responsible for the reduction in methane emissions. For example, it was reported by MAHMOUD et al. (2017) that the percentage of condensed tannins in the total tannin content of $C$. bipinnatus (same plant, same region) is $11.7 \%$, whereas that for $T$. erecta is only $1.2 \%$. This is in line with IVES et al. (2015), who evaluated the effect of condensed tannins from an extract of Acacia molissima $(50 \mathrm{~g} / \mathrm{Kg}$ of diet $\mathrm{DM})$ on in vitro $\mathrm{CH}_{4}$ production in five different species of ruminants and found that tannins from $A$. molissima reduced $\mathrm{CH}_{4}$ production by up to $12 \%$ in Holstein cows. Similarly,
MOREIRA et al. (2013) tested the effect of condensed tannins from Leucaena leucocephala, Styzolobium aterrimum and Mimosa caesalpiniaefolia on $\mathrm{CH}_{4}$ production in sheep, and reported that condensed tannins $(40 \mathrm{~g} / \mathrm{Kg}$ of diet DMI) of L. leucocephala reduced $\mathrm{CH}_{4}$ production by $25 \%$, S. aterrimum by only $1 \%$, while M. caesalpiniaefolia increased it by $7 \%$. However, they had to increase the inclusion level of L. leucocephala and $S$. aterrimum by up to $82 \%$ and $69 \%$, respectively, in order to achieve the reduction reported. Furthermore, at the inclusion level employed by MOREIRA et al. (2013), it is difficult to elucidate if the mitigation effect can be attributed to the condensed tannins in the legumes alone, as they stated, to other secondary metabolites in the plants (VERCOE 2015), or to the chemical composition of the plants themselves. This is because it is well established that diets with a high content of legumes produce less $\mathrm{CH}_{4}$, due to their low fiber content, than diets rich in grasses (ARNDT et al., 2014). TAVENDALE et al. (2005), who conducted an in vitro experiment to evaluate the $\mathrm{CH}_{4}$-reducing potential of Lotus pedunculatus and Medicago sativa, also reported a discrete reduction in $\mathrm{CH}_{4}$ production. They observed that $M$. sativa reduced $\mathrm{CH}_{4}$ production by $5 \%$ despite the fact that it only had $0.2 \mathrm{~g} / \mathrm{kg}$ of DM of condensed tannins, whereas L. pendunculatus, with a higher concentration of condensed tannins (107g/ $\mathrm{kg}$ of DM), had no effect on $\mathrm{CH}_{4}$ production. The approximate content of condense tannins of the diet with $C$. bipinnatus was $0.28 \mathrm{~g} / \mathrm{Kg}$ of diet $\mathrm{DM}$, which is very similar to that reported by TAVENDALE et al. (2005). Indeed, it seems that the $\mathrm{CH}_{4}$ reduction potential of tannins is not dose dependent, because high doses do not always lead to less $\mathrm{CH}_{4}$ production (BHATTA et al., 2009); whereas "low doses, as in the present study, seem to produce similar effects to those reported by the previous authors. This pattern of response was elegantly demonstrated by MAHMOUD et al. (2017) in an in vitro experiment that established 
that the response is not linear, but quadratic, and that there is an interaction $(\mathrm{P}<0,01)$ between the plants species and the level of inclusion in the diet for $\mathrm{CH}_{4}$ production. The positive associations between $\mathrm{CH}_{4} \mathrm{~L} /$ day and DMI $(\mathrm{r}=0.5, \mathrm{P}<0,05)$ and between DMD and $\mathrm{CH}_{4} \mathrm{~L}$ /day have been reported before, because intake is the most important variable that determines $\mathrm{CH}_{4}$ production; similarly, more $\mathrm{CH}_{4}$ will be produced in response to more degraded substrate (HALES et al., 2013). In contrast, the negative association observed between milk yield and $\mathrm{CH}_{4}$ in $\mathrm{L} / \mathrm{Kg}$ of milk has been reported before by GARG et al. (2013) where increased milk yield per cow was associated with lower methane production per kilogram of milk produced. In fact, intensification of milk production is considered an option for mitigating $\mathrm{CH}_{4}$ production in dairy systems (GERBER et al., 2011).

\section{CONCLUSION}

It can be concluded that supplementation at low doses with $C$. bipinnatus has the potential to reduce ruminal methane production in dairy cows without affecting animal production parameters. More research is needed in order to determine whether higher levels of C. bipinnatus may lead to further reduction in rumen methanogenesis. Also more research is needed for higher supplementation doses of $T$. erecta because it showed a trend towards reducing methanogenesis.

\section{ACKNOWLEDGEMENTS}

The authors acknowledge the financial support from the Molina Center for Energy and the Environment (UNEP Contract GFL-4C58), the Universidad Autónoma del Estado de México (grant UAEM 3474/2013CHT), and CONACYT (grant CB2013223418). Gloria Hernández-Pineda thanks CONACYT, Mexico for the scholarship for her MSc. The advice of Dr. Juan Carlos Ángeles-Hernández on the statistical analysis is acknowledged.

\section{DECLARATION OF CONFLICTING OF INTERESTS}

The authors declare no conflict of interest. The founding sponsors had no role in the design of the study; in the collection, analyses, or interpretation of data; in the writing of the manuscript, and in the decision to publish the results.

\section{BIOETHICS AND BIOSECURITY COMMITTEE APPROVAL}

All the experimental procedures were approved by the Committee on Bio-ethics and Animal Welfare of the Universidad Autónoma del Estado de México on the 24 ${ }^{\text {th }}$ of April 2015.

\section{AUTHORS' CONTRIBUTIONS}

The authors contributed equally to the manuscript.

\section{REFERENCES}

AOAC International. 1997. Official Methods of Analysis. 16th ed. AOAC Int., 344 Gaithersburg, Maryland : Association of Official Analytical Chemists International.

ARNDT C, et al, Performance digestion, nitrogen balance, and emission of manure, ammonia, enteric methane, and carbon dioxide in lactating cows fed diets with varying alfalfa silage-to corn silage ratios. J. Dairy Sci, v.98, p.418-430, 2014. Available from: <https:// www.journalofdairyscience.org/article/S0022-0302(14)00774-7/ pdf $>$. Accessed: Aug. 29, 2018. doi: 10.3168/jds.2014-8298.

ANDRADE RE, et al. Producción de metano utilizando plantas taníferas como substrato en fermentación ruminal in vitro y efecto de extractos fenólicos en la microflora ruminal. Trop Sub Agro, v.15, p.301-312, 2012. Available from: <http://www.revista.ccba.uady.mx/ urn:ISSN:1870-0462-tsaes.v15i2.841>. Accessed: Aug. 29, 2018.

BATES D, et al. Fitting Linear Mixed-Effects Models Using Ime4. Journal of Statistical Software. 2015: 67(1): 1-48. Available from: $<$ https://www.jstatsoft.org/article/view/v067i01/0>. doi: 10.18637/ jss.v067.i01. Accessed: Aug. 29, 2018.

BEAUCHEMIN KA, et al. Use of condensed tannin extract from quebracho trees to reduce methane emissions. J. Anim. Sci. 85; 1990-1996, 2007. Available from: <https://academic.oup.com/ jas/article-abstract/85/8/1990/4778278? redirectedFrom=fulltext $>$. doi: 10.2527/jas.2006-686. Accessed: Aug. 29, 2018.

BHATTA R, et al. Difference in the nature of tannins on in vitro ruminal methane and volatile fatty acid production and on methanogenic archaea and protozoal populations. J. Dairy Sci. 2009; 92:5512-5522. Available from: <https://www. journalofdairyscience.org/article/S0022-0302(09)70886-0/pdf>. doi: 10.3168/jds.2008-1441. Accessed: Aug. 29, 2018.

CHARMLEY E, et al. A universal equation to predict methane production of forage-fed cattle in Australia. Anim. Prod. Sci. 2016; 56: 2-3. Available from: <http://www.publish.csiro.au/AN/ an15365>. doi: 10.1071/AN15365. Accessed: Aug. 29, 2018.

CUARTAS CA, et al. Contribution of intensive silvopastoral systems to animal performance and to adaptation and mitigation of climate change. Rev. Colomb. Cienc. Pecu. 2014; 27:76-94. Available from: <http://www.scielo.org.co/scielo.php?script=sci_arttext\&pid $=$ S0120-06902014000200003 $>$. Accessed: Aug. 29, 2018.

GARG MR, et al. Effects of feeding nutritionally balanced rations on animal productivity, feed conversion efficiency, rumen microbial protein supply, parasitic load, immunity and enteric methane emissions of milking animals under field conditions. Anim. Feed. Sci. and Tech. 2013; 179: 24-35. Available from: $\quad<$ https://www.sciencedirect.com/science/article/pii/ S0377840112003902>. doi: 10.1016/j.anifeedsci.2012.11.005. Accessed: Aug. 29, 2018.

GERBER P, et al. Productivity gains and greenhouse gas emissions intensity in dairy systems. Liv. Sci. 2011; 139: 100-108. Available from: <https://www.sciencedirect.com/science/article/ pii/S1871141311000953>. doi: 10.1016/j.livsci.2011.03.012. Accessed: Aug. 29, 2018.

HAIGH PM. A note on the relationship between oven and toluene 374 determined dry matter concentrations in Maize silages. Irish J. Agr. Food. Res. 1995; 375 (34): 193-195. 
HALES KE, et al. Effects of increasing concentrations of wet distillers grains with solubles in steam-flaked, corn-based diets on energy metabolismo, carbono-nitrogen balance, and methane emissions of cattle. J. Anim. Sci. 2013; 91:819-828. Available from: $<$ https://pdfs semanticscholar.org/2d4d/9a6d9a817c3b7db728d22f09f4eb80116 2f9.pdf $>$. doi:10.2527/jas2012-5418. Accessed: Aug. 29, 2018.

Intergovernmental Panel on Climate Change (IPCC). Summary for Policymakers. En: Climate Change. Mitigation of climate change. Contribution of Working Group III to the fifth Assessment Report of the Intergovernmental Panel on Climate Change. 2014.

IVES $\mathrm{CV}$, et al. In vitro methane production and tolerance to condensed tannins in five ruminant species. Animal Feed Science and Technology. 2015; 205:1-9. Available from: $<$ https://www. sciencedirect.com/science/article/pii/S037784011500108X>. doi: 10.1016/j.anifeedsci.2015.03.008. Accessed: Aug. 29, 2018.

KAPS M, LAMBERSON W. Biostatistics for animal science: an introductory text. 2nd Ed. CABI. Oxfordshire, UK, 2009. 244-245p.

LENTH RV. Least-Squares Means: The R Package lsmeans. Journal of Statistical Software. 2016: 69(1): 1-33.

Makkar HS, et al. Gravimetric determination of tannins and their correlations with chemical and protein precipitation methods. Journal of the Science of Food and Agriculture. 1993; 61:161-165. Available from: <https://onlinelibrary.wiley.com/doi/ abs/10.1002/jsfa.2740610205>. doi: 10.1002/jsfa.2740610205. Accessed: Aug. 29, 2018.

MAHMOUD GR, et al. Reduction of methane production from ruminant livestock using tropical tanniferous plants: a sustainable option for mitigation. In Proceedings of the 6th Greenhouse Gas and animal Agriculture Conference, Melbourne, Australia, February 14 to 18,2016 . PO 119.

MAHMOUD GR, et al. Effect of tanniferous plants on in vitro digestion and methane production. Ecosist. Recur. Agropec. 2017. 4(11):371-380. Available from: <http://era.ujat.mx/index. php/rera/article/view/1160>. doi: 10.19136/era.a4n11.1160. Accessed: Aug. 29, 2018.

MOREIRA GD, et al. Tropical tanniniferous legumes used as an option to mitigate sheep enteric methane emission. Trop. Anim. Health Prod. 2013; 45:879-882. Available from: $<$ https://link. springer.com/article/10.1007/s11250-012-0284-0>. doi: 10.1007 . Accessed: Aug. 29, 2018.

NAUMANN DH, et al. Effect of molecular weight of condensed tannins from warm-season perennial legumes of ruminal methane production in vitro. Biochemical Systematics and Ecology. 2013; 50:154-162. Available from: <https://www.sciencedirect. com/science/article/pii/S0305197813000963>. doi: 10.1016/j. bse.2013.03.050. Accessed: Aug. 29, 2018.
NIU M, et al. Effect of dietary crude protein and forage contents on enteric methane emissions and nitrogen excretion from dairy cows simultaneously. Anim. Prod. Sci. 2016; 56:312-321. Available from: <http://www.publish.csiro.au/an/an15498>. doi: 10.1071/ AN15498. Accessed: Aug. 29, 2018.

PATRA AK, SAXENA J. A new perspective on the use of plant secondary metabolites to inhibit methanogenesis in the rumen. Phytochemistry 2010; 71: 1198-1222. Available from: $\quad<$ https://www.sciencedirect.com/science/article/abs/pii/ S0031942210001858>. doi: 10.1016/j.phytochem.2010.05.010. Accessed: Aug. 29, 2018.

PEDRAZA-BELTRÁN PE, et al. Construction and operation of the first low cost ventilated-hood system for methane measurements in cattle in Mexico. In Proceedings of the 6th Greenhouse Gas and Animal Agriculture Conference, Melbourne, Australia, February 14 to 18,2016 . PO 07.

PIÑEIRO-VÁZQUEZ AT, et al. Intake, digestibility, nitrogen balance and energy utilization in heifers fed low-quality forage and Leucaena leucocephala. Anim. Feed Sci. and Tech. 2017 (228): 194-201. Available from: <https://www.sciencedirect. com/science/article/pii/S037784011630623X>. doi: 10.1016/j. anifeedsci.2017.04.009. Accessed: Aug. 29, 2018.

TAVENDALE MH, et al. Methane production from in vitro rumen incubations with Lotus Pedunculatus and Medicago sativa, and effects of extractable condensed tannin fractions on methanogenesis. Animal Feed Science and Technology, 2005; 124:403-419. Available from: $<$ https://www.sciencedirect.com/science/article/ pii/S037784010500180X>. doi: 10.1016/j.anifeedsci.2005.04.037. Accessed: Aug. 29, 2018.

R Development Core Team (2011), R: A Language and Environment for Statistical Computing. Vienna, Austria: the R Foundation for Statistical Computing. ISBN: 3-90005107-0. Available from: <http://www.R-project.org/>. Accessed: Aug. 29, 2018.

VAN SOEST PJ, et al. Methods for dietay fiber, neutral detergent fiber and non-starch polysaccharides in relation to animal nutrition. J. Dairy Sci. 1991; 74:3583-3597. Available from: <https://www. sciencedirect.com/science/article/pii/S0022030291785512>. doi: 10.3168/jds.S0022-0302(91)78551-2. Accessed: Aug. 29, 2018.

VERCOE P. The mechanism of antimethanogenic bioactivity of plants in the rumen. Final Report. Meat \& Livestock Australia Limited. 2015 Locked Bag 991 NORTH SYDNEY NSW 2059.

WOODWARD SL, et al. Does feeding sulla (Hedysarum coronarium) reduce emissions from dairy cows? Proc. New Zeal. Anim. Prod. 2002; 62: 227-230. Available from: <http://www. nzsap.org/system/files/proceedings/2002/ab02058.pdf>. Accessed: Aug. 29, 2018. 